\title{
UNIVERSITYOF
}

FORWARD

THINKING

WESTMINSTER用

WestminsterResearch

http://www.westminster.ac.uk/westminsterresearch

\section{Differences in personality and individual entrepreneurial orientation between entrepreneur students and non-entrepreneur students}

Wisudha, A., Kenyatta, G.A. and Rumondor, P.C.B.

This is a copy of the final version of a book chapter published by Routledge in Ashar Ariyanto, A. (Ed.), Muluk, H. (Ed.), Newcombe, P. (Ed.), Piercy, F. P. (Ed.), Poerwandari, E. (Ed.), Suradijono, S. R. (Ed.). (2017). Diversity in Unity: Perspectives from Psychology and Behavioral Sciences. London: Routledge on 30 October 2017, available online:

http://www.routledge.com/9781138626652

Open Access content has been made available under a Creative Commons AttributionNon Commercial-No Derivatives (CC-BY-NC-ND) license

The WestminsterResearch online digital archive at the University of Westminster aims to make the research output of the University available to a wider audience. Copyright and Moral Rights remain with the authors and/or copyright owners.

Whilst further distribution of specific materials from within this archive is forbidden, you may freely distribute the URL of WestminsterResearch: ((http://westminsterresearch.wmin.ac.uk/).

In case of abuse or copyright appearing without permission e-mail repository@westminster.ac.uk 


\title{
Differences in personality and individual entrepreneurial orientation between entrepreneur students and non-entrepreneur students
}

\author{
A. Wisudha \\ Department of Psychology, University of Westminster, London, UK \\ G.A. Kenyatta \\ Lumina Learning Indonesia, Jakarta, Indonesia \\ P.C.B. Rumondor \\ Faculty of Psychology, Bina Nusantara University, Jakarta, Indonesia
}

\begin{abstract}
Previous research using a student population reported a relationship between personality and Individual Entrepreneurial Orientation (IEO). This study attempts to address this area of interest in more detail by investigating where there might be a difference between students who already have an established venture (Entrepreneur students) and those who have not as yet put their plans into action (Non-entrepreneur students). This study compares total IEO score and 4 out of 8 Lumina Spark aspects of personality between Entrepreneur students and Non-entrepreneur students. A sample of 292 students in 18-26 year age range from the Bina Nusantara University (BINUS) in Indonesia, consisting of Entrepreneur students $(\mathrm{n}=146)$ and Non-entrepreneur students $(\mathrm{n}=146)$ was administered IEO and Lumina Spark questionnaires. The IEO questionnaire measures Risk taking, Proactiveness, and Innovativeness. The Lumina Spark questionnaire is a psychometric instrument that uses the Big Five personality model as its cornerstone and a Jungian lens to inform the model. It measures 8 aspects: Inspiration Driven, Big Picture Thinking, Extraverted, Outcome Focused, Discipline Driven, Down to Earth, Introverted and People Focused. Independent T-tests showed statistically significant differences in total IEO, Risk-taking and Innovativeness dimensions of IEO, also in Big Picture Thinking, and Extraverted aspects of personality. In view of the practical implications that can be derived from the study, the subsequent discussion refers to the importance of awareness about IEO and personality in entrepreneurial education.
\end{abstract}

\section{INTRODUCTION}

Entrepreneurship has recently become the focus of attention amongst a number of disciplines. Entrepreneurship is seen as central to the enhancement of a country's economic growth (Seth, 2015). Therefore, an increase in the number of successful start-up businesses will arguably contribute to the rise in job opportunities and the generation of new wealth, leading to positive impact on measures of quality of life.

Entrepreneurship is defined as the identification and exploitation of business opportunities within the individual-opportunity nexus (Shane \& Venkantraman, 2000). According to Baron (2007), entrepreneurship as a process is made up of three phases: (a) the pre-launch or opportunity identification phase in which the entrepreneur identifies viable and feasible business opportunities, (b) the launch or development and execution phase in which the entrepreneur assembles the necessary resources for starting a venture, and (c) the post-launch phase in which the entrepreneur manages the new venture in such a way that it grows and survives. Entrepreneurship brings with it a greater freedom of choice of businesses and the 
flexibility in which it can be executed. These are attractive factors for the young generation who seek independence and flexible choice of opportunities. This is also demonstrated by the increased percentage of new enterprises initiated by Indonesia's young generation. Data from a survey on 'Becoming an Entrepreneur' conducted by Kompas' Research and Development reported that the largest age group from which entrepreneurs emerge is between 20-40 years old (Gianie, 2015).

In Indonesia, both private and government sectors are beginning to give their support to meet the entrepreneurial demands of young people. This ranges from providing boot camps, funding opportunities, mentoring schemes, longitudinal workshops, incorporating entrepreneurial education in almost all universities across disciplines, and many other activities. The government has even dedicated 100 billion USD to help this cause. The Creative Economy Council (BEKRAF) recently launched their newest program called BEKUP that stands for "BEKRAF for Pre-startups" this year (Palupi, 2016). In Jakarta and other large cities in Indonesia, a number of educator-curator bodies have been created that provide communities for entrepreneurs to collaborate as well as give and attend workshops, such as Lingkaran.co., maubelajarapa.com, Indoestri, and many more. Moreover since 2009, the Directorate General of Higher Education (DITJEN DIKTI) has made entrepreneurship a compulsory part of courses in the curriculum regardless of the students' major (BSI Entrepreneur Center, 2016). Many major Universities across Indonesia are committed to designing and implementing their curriculum to include the topic of entrepreneurship, as well as establishing entrepreneurial support centers for their students. Such commitment has been implemented, for example, in University of Indonesia, Institute of Technology Bandung, Pelita Harapan University, and Bina Nusantara University. All of these initiatives have been designed to support the growth in the number of successful and sustainable entrepreneurial businesses for students, regardless of their respective industry.

One model that provides a framework to study entrepreneurial success through a psychological perspective is the action-characteristic model developed by Frese \& Gielnik (2014). This model suggests that personality can influence entrepreneurial success through action characteristics such as personal initiative, goals/vision, search for opportunities, information search, planning, feedback processing, social networking, seeking of niche, seeking of resources, deliberate practice and entrepreneurial orientation. In the meta-analysis conducted by the authors, entrepreneurial orientation was shown to have a relatively higher correlation with business performance compared to other action-characteristics. In accordance with their findings, the current study will focus on personality as a factor that influences entrepreneurial success, and Individual Entrepreneurial Orientation (IEO) as action characteristics that can mediate the influence of personality on entrepreneurial success.

Entrepreneurial Orientation (EO) can be described as strategic processes in organizations that focus on the actions and decisions within an entrepreneurial context (Guth \& Ginsberg, 1990; Zahra \& Covin, 1995; Rauch, Wiklund, Lumpkin \& Frese, 2009). One strand of research into entrepreneurship has shown that EO has a remarkable influence on an organization's performance, profitability, growth and product innovation (Johan \& Dean, 2003; Avlontis \& Salavou, 2007; Moreno \& Casillas, 2008; Tang, Kacmar \& Busenitz, 2012). Studies of EO and its relation to company performance have consistently shown highly significant correlations (Fairoz, Hirobumi \& Tanaka, 2010; Schillo, 2011; Mahmood \& Hanafi 2013; Zulkifli \& Rosli, 2013). Moreover, EO at the organizational level has been shown to correlate with entrepreneurial performance (Koenig, Steinmetz, Frese, Rauch \& Wang, 2009).

EO was first measured within an organizational context and was characterized by the following factors: Autonomy, Innovativeness, Risk-taking, Proactiveness and Competitive Aggressiveness (Lumpkin \& Dess, 1996). Items on the EO scale at the organizational level assess the strategic stance adopted by top managers, the CEO, or general directors (Frese \& Gielnik, 2014). Organizations with a high entrepreneurial orientation outperform other firms because Autonomy, Innovativeness, Risk-taking, Proactiveness, and Competitive Aggressiveness collectively have been shown to help the company to seek and exploit new opportunities for growth (Lumpkin \& Dess, 1996). 
An organization, particularly a small or entrepreneurially-founded one, can be considered to result from an individual's inspiration and related behaviors. Following this, EO dimensions can also be measured at this individual level (Bolton \& Lane, 2012; Frese \& Gielnik, 2014). Among the five dimensions of EO, three dimensions have been identified and used consistently in the literature; those dimensions are Risk-taking, Innovativeness and Proactiveness (Miller, 1983; Bolton \& Lane, 2012). This study adopts previous definitions of EO, but places an emphasis on the individual level that focuses on actions and decisions within an entrepreneurial context, measured by an IEO scale adapted from Bolton and Lane (2012). This is also in line with Frese \& Gielnik's (2014) description of action characteristic as not action per se but they are rather ways of performing an action. Therefore, this study considers IEO, which consists of Risk-Taking, Innovativeness and Proactiveness, as action characteristics.

Our previous research found that there is a significant correlation between IEO and personality (Wisudha, Kenyatta, Rumeser, Rumondor, \& Andangsari, 2016). The research used a 20-item IEO questionnaire in Bahasa Indonesia, adapted from Bolton \& Lane (2012) and the 144-item Lumina Spark personality questionnaire (Desson, Benton, \& Golding, 2014). Lumina Spark was chosen because it treats all personality traits equally. It measures all traits independently and does not infer the strength of one traits at the expense of its opposite. For instance, Introverted traits will have their own directly measured scores, which are not inferred from the scores of Extraverted traits. This therefore allowed us to explore a comprehensive set of personality traits. The results from the research showed that all of the personality aspects, as measured by the Lumina Spark model, correlated significantly with IEO dimensions, even though the degree of correlations vary from moderate to strong $(r=0.28$ to 0.71). Four of the strongest degree of correlations were shown between IEO and the personality aspects: Big Picture Thinking; Extraverted; Outcome Focused and Discipline Driven.

Our previous research however did not look at differences between Entrepreneur and Non-entrepreneur students, unlike the study conducted by Kropp, Lindsay, \& Shoham (2008) that reported significantly different scores of IEO between Entrepreneurs and Nonentrepreneurs. In this study, we aim to address whether there is a difference in the IEO scores and the personality measures between these two groups. Our findings may inform stakeholders in entrepreneurial education of IEO dimensions and personality aspects that contribute to promoting and developing entrepreneurship. It has been reported that self-awareness of one's internal state, emotion, resource and intuition is related to higher job performance in general (Joseph, Jin, Newman, \& O'Boyle, 2015) as well as with entrepreneurs' business outcomes (Cross \& Travaglione 1995; Ahmetoglu, Leutner, \& Chamorro-Premuzic, 2011). Therefore, if action characteristics such as Risk-Taking, Innovativeness and Proactiveness, and personality aspects such as Big Picture Thinking, Extraverted, Outcome Focused, and Discipline Driven are statistically different between Entrepreneur and Non-entrepreneur students, this will enable those engaged in entrepreneurial education to help raise awareness in students and to provide guidance for educators in the preparation of the type and form of materials that are tailored to cater for both groups of students.

We hypothesized that there would be a significant difference in IEO and its dimensions (Risk Taking, Innovativeness and Proactiveness) between Entrepreneur and Non-entrepreneur students. Since personality was found to correlate with IEO (Wisudha et al., 2016), we also hypothesized that there would be a significant difference between Entrepreneur and Non-entrepreneur students in the four personality aspects which indicates the strongest degree of correlation, namely: Big Picture Thinking; Extraverted; Outcome Focused and Discipline Driven in Wisudha et al. (2016).

\section{METHODS}

Our previous research investigated the correlation between IEO and Personality using the Lumina Spark personality questionnaire with 585 participants from Bina Nusantara University students across faculties and semesters (Wisudha et al., 2016). There were 146 participants 
who reported that they had their own venture (Entrepreneurs) and 439 participants who reported no venture ownership (Non-entrepreneurs). The operational definition of 'entrepreneur' in this research was based on a self-report on whether or not they owned ventures or small businesses in various industries. Using SPSS, we took a random sample from the Nonentrepreneur students so it matched the sample amount of Entrepreneur students, which was 146 individuals.

The participants of this research were students from Bina Nusantara University, in age range of 18 to 26 years $(\mathrm{N}=292)$ taken from the study. The demographic profile of the respondents was $54.5 \%$ males and $45.5 \%$ females. Meanwhile, $90 \%$ of the respondents were in the age range of 18-22 years. Other demographics showed that $58 \%$ of the respondents were in their senior years (5th semester and above). The participants were students from eight different faculties in Bina Nusantara University, namely the Faculty of Humanities (26\%), Faculty of Economics and Communication (18.2\%), School of Information Systems (13.4\%), School of Computer Science (13\%), School of Design (11.3\%), Faculty of Engineering $(12.7 \%)$ and School of Business Management (5.5\%).

In this study, IEO was measured using a 20-item, five-point Likert scale questionnaire in Bahasa Indonesia, adapted from Bolton and Lane (2012), on three dimensions namely, Risk-Taking ( $\alpha=.81)$, Innovativeness $(\alpha=0.85)$, and Proactiveness $(\alpha=0.77)$. Personality was measured using the Lumina Spark personality questionnaire (Lumina Learning 2013), comprising of 144 items on a five-point Likert scale in Bahasa Indonesia. Four personality aspects were measured namely: Big Picture Thinking $(\alpha=0.86)$; Extraverted $(\alpha=0.87)$; Outcome Focused $(\alpha=0.86)$; and Discipline Driven $(\alpha=0.80)$. These four personality aspects showed the highest degree of correlation in a previous study (Wisudha et al., 2016).

\section{RESULTS}

Independent-sample t-tests were conducted to compare the IEO between Entrepreneur and Non-entrepreneur students, and to compare the Lumina Spark measures between the two groups. As presented in Table 1, there is a statistically significant difference in the total IEO scores between Entrepreneur students and Non-entrepreneur students. This suggests that IEO in Entrepreneur students is significantly higher than Non-entrepreneur students, although the magnitude of the differences in the means varies at the dimensional level from medium for Risk-taking and Innovativeness, to small for Proactiveness. Entrepreneur students tend to take more risks and are more innovative. As for Proactiveness, there is no significant difference between the two groups.

In terms of personality, there are significant statistical differences between Entrepreneur and Non-Entrepreneur students in two out of four Lumina Spark aspects being measured in this study, i.e., Big Picture Thinking and Extraverted, as presented in Table 2. This suggests that compared to the Non-Entrepreneur students, the Entrepreneur students are more flexible and like to let the direction of behavior emerge from an evolving situation; they are more

Table 1. Differences between Entrepreneur and Non-entrepreneur students in IEO measure.

\begin{tabular}{|c|c|c|c|c|c|c|c|c|c|c|}
\hline \multirow{2}{*}{$\begin{array}{l}\text { Individual } \\
\text { entrepreneurial } \\
\text { orientation }\end{array}$} & \multicolumn{2}{|c|}{$\frac{\begin{array}{l}\text { Non- } \\
\text { entrepreneur }\end{array}}{(n=146)}$} & \multicolumn{2}{|c|}{$\frac{\text { Entrepreneur }}{(n=146)}$} & \multirow{2}{*}{$\begin{array}{l}\text { Mean } \\
\text { difference }\end{array}$} & \multirow[b]{2}{*}{$t$} & \multirow[b]{2}{*}{$p$} & \multirow[b]{2}{*}{ Cohen's d } & \multicolumn{2}{|c|}{$\begin{array}{l}95 \% \text { confidence } \\
\text { interval of the } \\
\text { difference }\end{array}$} \\
\hline & M & SD & M & $\mathrm{SD}$ & & & & & Lower & Upper \\
\hline Proactiveness & 3.53 & 0.58 & 3.66 & 0.60 & 0.13 & -1.90 & 0.058 & 0.22 & -0.004 & 0.269 \\
\hline Risk taking & 3.47 & 0.63 & 3.79 & 0.61 & 0.32 & -4.40 & 0.000 & 0.52 & 0.177 & 0.464 \\
\hline Innovativeness & 3.51 & 0.56 & 3.72 & 0.63 & 0.21 & -3.03 & 0.003 & 0.35 & 0.074 & 0.348 \\
\hline IEO & 3.50 & 0.53 & 3.72 & 0.55 & 0.22 & -3.52 & 0.000 & 0.41 & 0.098 & 0.345 \\
\hline
\end{tabular}


Table 2. Differences between Entrepreneur and Non-entrepreneur Students in the personalitymeasure.

\begin{tabular}{|c|c|c|c|c|c|c|c|c|c|c|}
\hline \multirow[b]{3}{*}{ Lumina spark } & \multirow{2}{*}{\multicolumn{2}{|c|}{$\begin{array}{l}\begin{array}{l}\text { Non- } \\
\text { entrepreneur }\end{array} \\
(n=146)\end{array}$}} & \multirow{2}{*}{\multicolumn{2}{|c|}{$\begin{array}{l}\text { Entrepreneur } \\
(\mathrm{n}=146)\end{array}$}} & \multicolumn{4}{|c|}{$\begin{array}{l}\text { Mean } \\
\text { difference }\end{array}$} & \multirow{2}{*}{\multicolumn{2}{|c|}{$\begin{array}{l}95 \% \text { confidence } \\
\text { interval of the } \\
\text { difference }\end{array}$}} \\
\hline & & & & & & & $p$ & Cohen's d & & \\
\hline & M & SD & M & SD & & $t$ & & & Lower & Upper \\
\hline $\begin{array}{l}\text { Big Picture } \\
\text { Thinking }\end{array}$ & 3.39 & 0.55 & 3.52 & 0.53 & 0.13 & -2.01 & 0.05 & 0.24 & 0.03 & 0.25 \\
\hline Extraverted & 3.44 & 0.54 & 3.64 & 0.55 & 0.19 & -3.04 & 0.00 & 0.37 & 0.07 & 0.32 \\
\hline $\begin{array}{l}\text { Outcome } \\
\text { Focused }\end{array}$ & 3.38 & 0.57 & 3.49 & 0.50 & 0.11 & -1.71 & 0.09 & 0.20 & -0.02 & 0.23 \\
\hline $\begin{array}{l}\text { Discipline } \\
\text { Driven }\end{array}$ & 3.65 & 0.47 & 3.69 & 0.45 & 0.03 & -0.61 & 0.54 & 0.13 & -0.07 & 0.14 \\
\hline
\end{tabular}

visionary, willing to make improvements and shake up the status quo; furthermore, they enjoy working with other people, and are more expressive.

\section{DISCUSSION}

This study shows that there are statistically significant differences in total IEO between Entrepreneur and Non-entrepreneur students. At the dimension level, Risk-taking and Innovativeness show significant differences between the two groups. However, there is no difference seen for the Proactiveness dimension. Compared to total IEO and Innovativeness, Risk Taking has the biggest effect size $(\mathrm{d}=0.52)$. This is consistent with the findings made by Kropp et al. (2008) who found significant differences in Risk-taking $(\mathrm{d}=0.49)$ between Entrepreneurs (full time entrepreneurs) and Non-entrepreneurs (employees in companies). It is also consistent with Frese \& Gielnik's (2014) Model of Entrepreneurship that uses IEO as one of the predictors of entrepreneurial success. In their study, the effect size of IEO to entrepreneurship is seen to be medium $(\mathrm{d}=0.41)$.

There are several reasons which may explain the medium size of effect in the results. Firstly, the items constructed may not be sensitive enough to measure the essence of IEO, so there is a call for a review of the items. Linked to that, in view of the small mean differences, it is suggested that the Likert measurement scale can be refined and widened from five points to seven points. Secondly, in the questionnaire, the definition of entrepreneurship was limited to owning a venture; therefore, it is noted that the study is limited to investigating the second phase of entrepreneurship, the launch phase, comprising the development and execution phase. We can argue that IEO, especially Risk Taking and Innovativeness, is needed in this second phase, launching, though by only looking at the this phase, the indicators of entrepreneurship used in this research are not sufficiently comprehensive. It is noted that the research does not cover the first phase of entrepreneurship, namely the pre-launch or opportunity identification phase as well as the third phase which is concerned with maintaining the business. It is suggested that measurements be included for these two phases, which may result in a shift in the effect size of the IEO measures and where the role of Proactiveness may also become more evident.

In terms of personality, Lumina Spark's Big Picture Thinking and Extraverted are the personality aspects that measure significantly higher in Entrepreneur students $(p<0.05)$, with Extraverted having a higher effect size. This supports findings by Zhao Seibert and Lumpkin (2010) where correlations were found between Extraversion, Conscientiousness, and Openness with entrepreneurial intent and performance. Moreover, the researchers across disciplines have suggested that Extraversion predicts Risk-taking behavior in several contexts (Nicholson, Soane, Fenton-O'Creevy, \& Willman, 2005; Anic, 2007; Zafar \& Meenakshi, 2011). Although our previous research shows that all personality aspects correlate with IEO 
(Wisudha et al., 2016), the result from our current study suggests that Entrepreneur students have different personality characteristics compared to Non-Entrepreneur students. However, because this research only considers entrepreneurial status from self-reports by the participants, we can say that the result does not imply that other personality dimensions are not important for an entrepreneur.

There are several limitations to this study. Firstly, IEO was measured using a self-report questionnaire, while most recent research reported that there are other ways of measuring IEO to get a more holistic view, namely using the methodology of Assessment Centers. The Assessment Center approach is a method that can involve a unique combination of essential elements codified in Guidelines and Ethical Considerations of Assessment Center Operations that have been used for selection, diagnosis and development in organizations (Thornton \& Gibbons, 2009). It has recently been used to measure IEO (DeGennaro, Wright, \& Panza, 2016). Further research can adopt the Assessment Center method to measure the aspects of IEO that cannot be measured by a self-report scale, for example by having multiple trained assessors observe overt behavior displayed by an assessee in a complex entrepreneurial context. Secondly, this study is not able to provide a meaningful breakdown of information based on business industries as the list does not account for a large percentage of responses regarding that factor. The absence of a choice led $65 \%$ of respondents to choose "Other" when describing their business industry. Future research will benefit from using a refined list of entrepreneurial business industries that is updated in view of the expansion in recent times of types of entrepreneurial ventures. This will enable a more meaningful analysis based on business industries.

This research has provided an insight that risk-taking as an action characteristic has the largest impact on business ownership. Students who have their own business take more bold actions by going into the unknown and committing significant resources to ventures in an uncertain situation, compared to students who do not have their own business. Universities with entrepreneurial courses can develop curricula with activities that help students practice risk-taking in a business context. Risk-taking can be incorporated as one of the sessions, and therefore, training such as Achievement Motivation Training can be useful as one way to teach risk-taking to students. The module to teach risk-taking can also be developed into different forms of risk-taking in a business context, such as risk-taking about time, decision making, finance, and many more. Moreover, universities can use this result as evidence for programs that aim to help increase student's awareness of their personality trait, as it is related with entrepreneurial outcome. Students who have high scores on Big Picture Thinking and Extraverted can be encouraged to perceive it as a commodity for successful entrepreneurship. As for students with lower scores on those aspects, universities can develop programs to cultivate Big Picture Thinking and Extraverted aspects of their personality and/ or associated behaviors.

\section{CONCLUSION}

Our first hypothesis states that there is a significant difference in IEO and its dimensions (Risk Taking, Innovativeness, Proactiveness) between Entrepreneur and Non-entrepreneur students. Following the results, this hypothesis is partially supported, Entrepreneur students are reported to have higher Risk-taking and Innovativeness compared to Non-entrepreneur students. It suggests that Risk taking and Innovativeness are helpful dimensions to indicate whether or not a student is successful in starting a new business, with Risk taking having a bigger effect than Innovativeness. However, Proactiveness is shown to be statistically insignificant in determining a difference between both groups. Similarly, our second hypothesis also partially supports that the Big Picture Thinking and Extroverted aspects of Lumina Spark are higher in Entrepreneur students. The Entrepreneur students, however, do not differ from Non-entrepreneur students in terms of the Outcome Focused and Discipline Driven aspects of Lumina Spark. This result has provided supportive evidence 
for universities to develop curricula which include activities that help students practice risk-taking in a business context, increase students' awareness of their personality trait, and extend their range of behavior to embrace Big Picture Thinking and Extraversion aspects of their unique personality.

\section{REFERENCES}

Anic, G. (2007) The Association Between Personality and Risk Taking. [Master's Thesis], University of South Florida. Available from: http://scholarcommons.usf.edu/etd/605.

Avlontis, G.J., \& Helen, E.S. (2007) Entrepreneurial orientation of smes, product innovativeness, and performance. Journal of Business Research, 60 (5), 566-575. Available from: http://dx.doi.org/10.1016/j. jbusres.2007.01.001.

Ahmetoglu, G., Franziska, L., \& Tomas, C.P. (2011) EQ-nomics: Understanding the relationship between individual differences in trait emotional intelligence and entrepreneurship. Personality and Individual Differences 51, 1028-1033. doi:10.1016/j.paid.2011.08.016.

Baron, R.A. (2007) Entrepreneurship: A process perspective. In Baum J.R., Frese M, Baron R.A. (Eds) The Psychology of Entrepreneurship, 19-39. Mahwah, NJ, Erlbaum.

Bolton, D.L., \& Michele D.L. (2012) Individual entrepreneurial orientation: Development of a measurement instrument. Education and Training 54 (2), 219-233. doi:10.1108/00400911211210314.

BSI Entrepreneur Center. (2016) Saatnya Kampus Dijadikan Basis Produksi Entrepreneur. Available from: http://bec.bsi.ac.id/baca-artikel/2016/02/saatnya-kampus-dijadikan-basis-produksientrepreneur\#.V_sNjeB942x.

Cross, B., \& Anthony, T. (1995) The untold story: Is the entrepreneur of the 21 st century defined by emotional intelligence? International Journal of Organizational Analysis11 (3), 221-228. doi:10.1108/ eb028973.

DeGennaro, M.P., Chris W.W., \& Nancy, R.P. (2016) "Measuring Entrepreneurial Orientation in an Assessment Center: An Individual Level-of-Analysis Study."The Psychologist-Manager Journal, 19 (1), 1-22. Available from: doi:10.1037/mgr0000035.

Desson, S., Stephen, B., \& John, G. (2014) "Lumina Spark-Development of an Integrated Assessment of Big 5 Personality Factors, Type Theory and Overextension."International Conference on Psychotechnology Abstract Book. Available from: https://www.luminalearning.com/pdfs/SparkResearch. pdf.

Fairoz, F.M., Hirobumi, T., \& Tanaka, Y. (2010) Entrepreneurial orientation and business performance of small and medium scale enterprises of Hambantota District Sri Lanka. Asian Social Science, 6 (3), 34 46. Available from: doi: 10.5539/ass.v6n3p34.

Frese, M, \& Michael, M.G. (2014) The psychology of entrepreneurship. Annual Review of Organizational Psychology and Organizational Behavior, 1 (1), 413-438. Available from: doi:10.1146/annurevorgpsych-031413-091326.

Gianie. (2015) Berani Menjadi Wirausaha. Kompas Print. Available from: http://print.kompas.com/ baca/2015/04/21/Berani-Menjadi-Wirausaha.

Guth, W.D., \& Ari, G. (1990) Guest editors' introduction: Corporate entrepreneurship. Strategic Management Journal, 11, 5-15. Available from: http://www.jstor.org/stable/2486666.

Johan, W., \& Shepherd, D. (2003) Knowledge-based resources, entrepreneurial orientation, and the performance of small and medium-sized businesses. Strategic Management Journal, 24 (13), 1307-1314. doi: $10.1002 /$ smj.360.

Joseph, D.L., Jing, J., Daniel, A.N., Ernest, H.O.B. (2015) Why does self-report emotional intelligence predict job performance? A meta-analytic investigation of mixed EI. Journal of Applied Psychology, 100 (2), 298-342. doi:/10.1037/a0037681.

Koenig, C., Holger, S., Michael, F., Andreas, R., \& Zhong-Ming, W. (2007) Scenario-based scales measuring cultural orientations of business owners. Journal Evolutionary Economics, 17 (2), 211-239. doi: 10.1007/s00191-006-0047-z.

Kropp, F., Noel, J.L., \& Aviv, S. (2008) Entrepreneurial orientation and international entrepreneurial business venture startup. International Journal of Entrepreneurial Behavior and Research, 14 (2), 102 117. doi:10.1108/13552550810863080.

Lumina Learning. (2013) Lumina Spark Qualification Manual. Lumina Learning, Camberley, UK.

Lumpkin, G.T., \& Gregory, G.D. (1996) Clarifying the entrepreneurial orientation construct and linking it to performance. Academy of Management Review, 21 (1), 135-172. doi:10.2307/258632. 
Mahmood, R.N.H. (2013) Entrepreneurial orientation and business performance of women-owned small and medium enterprises in Malaysia : Competitive advantage as a mediator. International Journal of Business and Social Science, 4 (1), 82-90. doi:10.1177/0266242612455034.

Miller, D. (1983) The correlates of entrepreneurship in three types of firms. Management Science, 29 (7), 770-791. Available from: http://dx.doi.org/10.1287/mnsc.29.7.770.

Moreno, A.M., \& Jose, C.C. (2008) Entrepreneurial orientation and growth of SMEs: A causal model. Entrepreneurship Theory and Practice, 32 (3), 507-528. doi: 10.1111/j.1540-6520.2008.00238.x.

Nicholson, N., Emma, S., Mark, F.O.C., \& Paul, W. (2005) Personality and domain-specific risk taking. Journal of Risk Research, 8 (2), 157-176. doi:10.1080/1366987032000123856.

Palupi, H. (2016) BEKRAF Luncurkan Program BEKUP dalam Upaya Meningkatkan Keberhasilan PreStartup Indonesia. Available from: https://www.codepolitan.com/bekraf-luncurkan-program-bekupupaya-meningkatkan-keberhasilan-pre-startup-indonesia.

Rauch, A., Johan, W., Lumpkin, G.T., \& Michael, Frese. (2009) Entrepreneurial orientation and business performance: An assessment of past research and suggestions for the future. Entrepreneurship Theory and Practice, 33 (3), 761-787. doi: 10.1111/j.1540-6520.2009.00308.x

Schillo, S. (2011) Entrepreneurial orientation and company performance: Can the academic literature guide managers? Technology Innovation Management Review 1 (2), 20-25. http://timreview.ca/ article/497.

Seth, S. (2015) Why Entrepreneurs Are Important for the Economy. Available from: http://www.investopedia.com/articles/personal-finance/101414/why-entrepreneurs-are-important-economy.asp.

Shane, S, \& Venkataraman, S. (2000) The promise of entrepreneurship as a field of research. The Academy of Management Review, 25 (1), 217-226. Available from: http://www.jstor.org/stable/259271.

Tempo.co.id. (2016) Pemerintah Gelontorkan Rp 100 Triliun untuk Bantu Pengusaha Muda. Available from: https://m.tempo.co/read/news/2016/05/24/090773725/pemerintah-gelontorkan-rp-100-triliununtuk-bantu-pengusaha-muda.

Tang, J., Kacmar, K.M., \& Lowell, W.B. (2012) Entrepreneurial alertness in the pursuit of new opportunities. Journal of Business Venturing, 27 (1), 77-94. doi: 10.1016/j.jbusvent.2010.07.001.

Thornton, G.C., \& Alyssa, M.G. (2009) Validity of assessment centers for personnel selection. Human Resource Management Review, 19 (3), 169-187. doi:10.1016/j.hrmr.2009.02.002.

Wisudha, A., Gabriela, A., Johannes, R., Pingkan, C.B.R., \& Esther, W.A. (2016) The Correlation Between Personality and Individual Entrepreneurial Orientation: A Recommendation for Entrepreneurial Education.Proceeding of International Conference on Entrepreneurship (ICONENT), Tangerang, 2016. Available from: http://iconent.global.uph.edu/news.html.

Zafar, S. \& Meenakshi, K. (2012) A study on the relationship between extroversion-introversion and risk-taking in the context of second language acquisition. International Journal of Research Studies in Language Learning, 1 (1), 33-40. doi:10.5861/ijrsll.2012.v1i1.42.

Zahra, S.A., \& Jeffrey, G.C. (1995) Contextual influences on the corporate entrepreneurshipperformance relationship: A longitudinal analysis. Journal of Business Venturing, 10 (1), 43-58. doi:10.1016/0883-9026(94)00004-E.

Zhao, H., Scott, E.S., \& Lumpkin, G.T. (2010) The relationship of personality to entrepreneurial intentions and performance: A meta-analytic review. Journal of Management, 36 (2), 381-404. doi:10.1177/0149206309335187.

Zulkifli, R.M., \& Rosli, M.M. (2013) Entrepreneurial orientation and business success of malay entrepreneurs: Religiosity as moderator. International Journal of Humanities and Social Sciences, 3 (10), 264-275. Available from: http://www.ijhssnet.com/journals/Vol_3_No_10_Special_Issue_ May_2013/29.pdf 